\title{
Identification of a New, Unorthodox Member of the MAGE Gene Family
}

\author{
Mehis Põld, ${ }^{*}+{ }^{\prime 1}$ J in Zhou,*'† Grace L. Chen,*'† Jeffrey M. Hall,‡ Robert A. Vescio,†'§ \\ and James R. Berensont' $\S$
}

\begin{abstract}
*Brentwood Biomedical Research Institute and †Division of Hematology and Oncology, Veterans Affairs West Los Angeles M edical Center, 11301 Wilshire Boulevard, 111-H, Los Angeles, California 90073; §Jonsson Comprehensive Cancer Center and Division of Hematology and Oncology, University of California Los Angeles School of Medicine, 10833 LeConte Avenue, Los Angeles, California 90095; and ¥Axys Pharmaceuticals, 11099 North Torrey Pines Road, Suite 160, La Jolla, California 92037
\end{abstract}

Received February 8, 1999; accepted April 28, 1999

\begin{abstract}
Several tumor-associated antigen families, such as MAGE, GAGE/PAGE, PRAME, BAGE, and LAGE/NYESO-1, exist. These antigens are of particular interest in tumor immunology, because their expression, with exception of testis and fetal tissues, seems to be restricted to tumor cells only. We have identified a novel member of the MAGE gene family, MAGED1. Northern hybridization and RT-PCR demonstrated that the expression level of MAGED1 in different normal adult tissues is comparable to that in testis and fetal liver. Thus, MAGE D1 does not possess an expression pattern characteristic of previously identified MAGE family genes, suggesting that the biology of the MAGE-family genes is more complex than previously thought. Chromosome mapping linked MAGED1 to marker AF M119xd6 (DXS1039) on chromosome Xp11.23. ๑ 1999 Academic Press
\end{abstract}

\section{INTRODUCTION}

Several structurally unrelated tumor-associated and testis-specific antigen families, such as MAGE, GAGE/ PAGE, PRAME, BAGE, and LAGE/NY-ESO-1, have been identified. The members of these antigen families are of particular interest in tumor immunology, because their expression is thought to be restricted to tumor cells only (testis and fetal tissues excluded). The major histocompatibility complex I (MHC I) bound short peptides derived from these proteins are capable of activating tumor-cell-specific cytotoxic T-lymphocytes in vitro (Van den Eynde and van der Bruggen, 1997; Boël et al., 1995; Lethe et al., 1998). Experimen-

Sequence data for the MAGED1 cDNA have been deposited with the GenBank Data Library under Accession N os. Banklt 250580 and AF 124440.

${ }^{1}$ To whom correspondence should be addressed at Brentwood Biomedical Research Institute, VA West Los Angeles Medical Center, Building 304, E1-106, 11301 Wilshire Boulevard, Los Angeles, CA 90073. Telephone: (310) 478-3711, x44769. Fax: (310) 268-4694. Email: Maalpold@msn.com. tally, such activation can lead to anti-tumor responses (Mukherji et al., 1995; Hu et al., 1996; Marchand et al., 1995). In previous studies, we have shown that the multiple myeloma (MM) bone marrow stromal cells (BMSC), while being nonmalignant cells, harbor human herpes virus 8 (HHV-8) (Rettig et al., 1997). We have performed representational difference analysis (RDA) to identify the differences in gene expression of BMSC from MM patients compared to those from healthy donors. As a result, we have cloned a sequence that matches several human ESTs in the dbEST (the database of ESTs). Analysis of these ESTs in the tentative human consensus (THC) sequence database (dbTHC) at The Institute of Genomic Research (TIGR) matched them with the sequence THC179960, encoding a new member of the MAGE gene family, which we named MAGED1. ESTs (expressed sequence tags) are partial, single-pass sequences from either end of a cDNA clone. The EST strategy was developed to allow rapid identification of expressed genes by sequence analysis (Adams et al., 1993). THCs are consensus sequences based on two or more ESTs that overlap for at least 40 bases with at least $95 \%$ sequence identity. Cloning and sequencing confirmed the sequence of THC179960, and conceptual translation determined a 574-amino-acid protein with a strong MAGE family homology in its C-terminus. Interestingly, RT-PCR and Northern blots with a variety of poly $(A)^{+}$RNAs derived from normal adult tissues revealed that MAGED1 possesses an expression pattern not observed for the known members of this gene family. Namely, the MAGED1 mRNA is expressed in a wide variety of normal adult tissues. Quantitatively, the expression level of the MAGED1 mRNA in tissues such as normal adult pancreas, adrenal medulla, thyroid gland, adrenal cortex, heart, brain, and placenta is similar to that in the normal adult testis and fetal liver. Thus, our study suggests that the biology of the MAGE family genes is more complex than previously thought. 


\section{MATERIALS AND METHODS}

RDA. RDA was carried out as previously described using CDNA from the MM BMSC as the tester (Hubank and Schatz, 1994). After three rounds of amplification, the resulting predominant PCR products were cloned into the pCR2.1 cloning vector (Invitrogen) and sequenced.

BLAST search. The sequence analyses were performed using various BLAST searches at the National Center for Biotechnology Information and TIGR at www.ncbi.nlm.nih.gov/BLAST/ and Baylor College of Medicine (BMC) at dot.imgen.bcm.tmc.edu:9331.

Primers. The following primers were used: F1, CAGGCCAAAATGGCCACTTCCCAGGCT; F2, AGATGTGGCCCTTCTTCAGGAAAGA; R1, CTCAACCCAGAAGAAACCAATGGCACC; R2, GGGTCCTCTTGCCCCGAAT; R3, ATCTCAGCACTTTCATCTTG; RHF, CAATCGCAGTAGTCTTTCCC; RHR, CCAAAACTTGACAGCACACA; T7T, GTAATACGACTCACTATAGGGC $(T)_{18} ; \beta$-ACTF, AGGTCATCACCATTGGCAAT; $\beta$-ACTR, CATGATGGAGTTGAAGGTAGT.

Cells and RNA. Bone marrow aspirates were obtained from normal individuals and MM patients, and BMSC were cultured as previously described (Gartner and Kaplan, 1980). Total RNA was extracted using the TRIazol reagent (Gibco BRL) and poly $(A)^{+}$with the RNA Fast Track $2.0 \mathrm{Kit}$ (Invitrogen). In some experiments, commercially available poly(A) ${ }^{+}$RNA from normal adult bone marrow was used (Clontech Inc.).

Cloning of MAGED1. Reverse transcription with the R1 primer (Fig. 1) was carried out with Superscript (Gibco BRL) at $42^{\circ} \mathrm{C}$ for 50 min with 50 ng of normal bone marrow poly $(A)^{+}$RNA (Clontech) as a template. One-twentieth of the reverse-transcribed RNA was then subjected to 45 cycles of touchdown PCR with the Advantage GC CDNA Polymerase and 1.0 M GC-M elt, using primers F 1 and R1 (Fig. 1) under the reaction conditions recommended by the manufacturer (Clontech). The cycling conditions that we used were as follows: the initial hot start at $95^{\circ} \mathrm{C}$ for $2 \mathrm{~min}$ was followed by two reiterations of $30 \mathrm{~s}$ of denaturation at $94^{\circ} \mathrm{C}$ and a 1 -min annealing/extension step at $70^{\circ} \mathrm{C}$. For the next 2 cycles, the annealing/extension temperature was lowered to $68^{\circ} \mathrm{C}$. After the first 4 cycles of amplification, the annealing and extension steps were separated, with the extension step remaining constant at $68^{\circ} \mathrm{C}$ for $1 \mathrm{~min}$ and the temperature of the $30-\mathrm{s}$ annealing steps decreasing by $2^{\circ} \mathrm{C}$ every subsequent 2 cycles until the final annealing temperature of $58^{\circ} \mathrm{C}$ was reached. The 1.7-kb amplification product was then cloned into the vector pCR2.1 (Invitrogen) and sequenced using T7 primer, M13 Reverse primer, and a series of insert-specific primers.

RT-PCR. RT-PCR was carried out as follows: $\sim 1.0 \mu \mathrm{g}$ of total RNA from either normal or MM BMSC was reverse-transcribed at $42^{\circ} \mathrm{C}$ for $1 \mathrm{~h}$ with $\mathrm{M}-\mathrm{MLV}$ Reverse Transcriptase and TT primer (500 nM final concentration) in the buffer provided by the manufacturer (Gibco BRL). One-twentieth of the first-strand CDNA was then subjected to touchdown PCR as described above, except that the final annealing temperature was $66^{\circ} \mathrm{C}$ and 35 cycles in total were performed instead of 45 . I ncreasing the annealing temperature to $66^{\circ} \mathrm{C}$ enhanced the sensitivity of the PCR with $F 1$ and R1 primers. The specificity of the RT-PCR was confirmed by cloning and sequencing (see Cloning of the MAGED1). As a negative control, $200 \mathrm{ng}$ of human genomic DNA was PCR amplified in parallel to the BMSC samples.

PCR on CDNA library panels. PCR with F1 and R1 primers on CDNAs from various normal adult tissues was carried out using heat-inactivated cDNA library aliquots from the Quick-Screen Library Panel (Clontech Inc.) (for conditions, see RT-PCR).

Northern blots and hybridization probes. Multiple tissue Northern blots (MTB) were purchased from Clontech Inc. and hybridized with the probes F1R2 and F2R3. The 145-bp F1R2 probe was generated by PCR using primers F1 and R2 (Fig. 1), each at a $0.4 \mu \mathrm{M}$ concentration. The conditions of labeling were as follows: 200 pg of clone pMAGED1 (Fig. 1) in buffer A (Invitrogen's PCR Optimization Kit), supplied with unlabeled dGTP, dATP, and dTTP and $\left[{ }^{32} P\right] d C T P$ $(6000 \mathrm{Ci} / \mathrm{mmol})$ (Amersham), each at $3 \mu \mathrm{M}$, was amplified by $2.5 \mathrm{U}$ of AmpliTaq (Perkin-Elmer), with a hot start at $95^{\circ} \mathrm{C}$ for $2 \mathrm{~min}$ followed by $30 \mathrm{~s}$ of denaturation at $94^{\circ} \mathrm{C}, 30 \mathrm{~s}$ of annealing at $60^{\circ} \mathrm{C}$, and $1 \mathrm{~min}$ of extension at $72^{\circ} \mathrm{C}$, reiterated 44 times. To generate the 551-bp F 2R3 probe, the F2 and R3 primers (Fig. 1) were used under the same conditions as $F 1$ and R2, except that the annealing temperature was lowered to $55^{\circ} \mathrm{C}$. The 615 -bp actin probe was generated off the $\sim 1.0 \mu \mathrm{g}$ of total RNA from normal adult bone marrow and reverse-transcribed with Superscript (see above) using primer T7T. Then, $1 / 100$ of the CDNA was subjected to PCR amplification using primers $\beta$-ACTF and $\beta$-ACTR under the same conditions as the F IR2 probe, except that an annealing temperature of $58^{\circ} \mathrm{C}$ was used. All probes were denatured at $96^{\circ} \mathrm{C}$ for $5 \mathrm{~min}$, added to the prehybridization mix, and hybridized at $65^{\circ} \mathrm{C}$ for $7-17 \mathrm{~h}$ according to the user manual for the MTB.

Chromosome mapping. The mapping was carried out on GeneBridge 4 and G3 (Stanford Genome Center) radiation hybrid panels using PCR primers RHF and RHR (Fig. 1). Thirty-five cycles of PCR were carried out using $2.5 \mathrm{U}$ of AmpliTaq in the buffer supplied by the manufacturer (Perkin-EImer) and under the same cycling conditions used for the $\beta$-actin probe. Both panels were tested in triplicate.

\section{RESULTS}

\section{Identification of MAGED1, a Novel Member of the MAGE Gene Family}

By performing RDA, we cloned a DNA fragment that matched several ESTs in the dbEST. When the matching ESTs were screened through the dbTHC, one matching virtual transcript, THC179960, was identified. A conceptual translation of the complementary strand of TCH179960 revealed an ORF encoding a putative 574-amino-acid protein with strong homology to the members of the MAGE gene family in its Cterminus (Fig. 2A). Based on the structure of the virtual MAGE, we conclude that this MAGE represents a novel member of the MAGE family, which we call MAGED1. The N-terminal half of THC179960 contains a series of short, imperfect hexameric repeats, which seem to have been conserved in mammals. We have found similar repeat motifs in mouse ESTs (Fig. 2B). Interestingly, some of the ESTs assembled into THC179960 stem from the CDNA libraries made from normal adult tissues (Table 1). Therefore, we conclude that the mRNA of MAGED1 is also expressed in normal adult tissues.

\section{Cloning and Sequencing of MAGED1}

Using the $F 1$ and $R 1$ primers on reverse-transcribed bone marrow mRNA, we amplified the 1731-bp F1/R1 CDNA fragment (Fig. 1). The sequencing of this fragment confirmed the sequence of the portion of the TCH179960/M AGED1 that amplifies with the primers $F 1$ and R1. The F1/R1-amplified fragment of TCH179960 contains the portion of TCH179960 that encodes the putative 574-amino-acid protein (MAGED1), including the putative translation start site with the Kozak's consensus ATG:G (Kozak, 1987) 
CAGGC 640

$\begin{array}{llllllllllllllllllllllllllllllll}M & A & T & S & Q & A & D & I & E & T & D & P & G & I & S & E & P & D & G & & 19\end{array}$ CAAAATG GCC ACT TCC CAG GCT GAC ATA GAG ACC GAC CCA GGT ATC TCT GAA CCT GAC GGT 701 E1

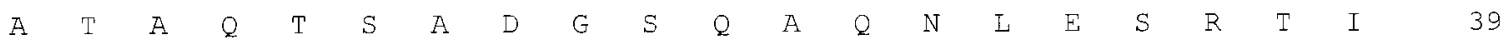
GCA ACT GCA CAG ACA TCA GCA GAT GGT TCC CAG GCT CAG AAT CTG GAG TCC CGG ACA ATA 761

$\begin{array}{llllllllllllllllllllllllllllll}I & R & G & K & R & T & R & K & I & N & N & I & N & V & E & E & N & S & S & G & 59\end{array}$

ATt CGg GGC AAg AGg ACC CGC AAG ATT AAT AAC TTG AAT GTT GAA GAG AAC AGC AGT GGG 821 R2

$\begin{array}{lllllllllllllllllllllllllllllll}\mathrm{D} & \mathrm{Q} & \mathrm{R} & \mathrm{R} & \mathrm{A} & \mathrm{P} & \mathrm{L} & \mathrm{A} & \mathrm{A} & \mathrm{G} & \mathrm{T} & \mathrm{W} & \mathrm{R} & \mathrm{S} & \mathrm{A} & \mathrm{P} & \mathrm{V} & \mathrm{P} & \mathrm{V} & \mathrm{T} & & 79\end{array}$ GAT CAG AGG CGG GCC CCA CTG GCT GCA GGG ACC TGG AGG TCT GCA CCA GTT CCA GTG ACC 881

$\begin{array}{lllllllllllllllllllllllll}\mathrm{T} & \mathrm{Q} & \mathrm{N} & \mathrm{P} & \mathrm{P} & \mathrm{G} & \mathrm{A} & \mathrm{P} & \mathrm{P} & \mathrm{N} & \mathrm{V} & \mathrm{L} & \mathbf{W} & \boldsymbol{Q} & \mathbf{T} & \mathrm{P} & \mathrm{L} & \mathbf{A} & \mathbf{W} & \boldsymbol{Q} & & 99\end{array}$ ACT CAG AAC CCA CCT GGC GCA CCC CCC AAT GTG CTC TGG CAG ACG CCA TTG GCT TGG CAG 941

$\begin{array}{lllllllllllllllllllll}\mathrm{N} & \mathrm{P} & \mathrm{S} & \mathrm{G} & \mathrm{W} & \mathrm{Q} & \mathrm{N} & \mathrm{Q} & \mathrm{T} & \mathrm{A} & \mathrm{R} & \mathrm{Q} & \mathbf{T} & \mathrm{P} & \mathrm{P} & \mathrm{A} & \mathrm{R} & \mathrm{Q} & \mathbf{S} & \mathrm{P} & 119\end{array}$ AAC CCC TCA GGC TGG CAA AAC CAG ACA GCC AGG CAG ACC CCA CCA GCA CGT CAG AGC CCT 1001 $\begin{array}{lllllllllllllllllllll}\mathrm{P} & \mathrm{A} & \mathrm{R} & \mathrm{Q} & \mathrm{T} & \mathrm{P} & \mathrm{P} & \mathrm{A} & \mathrm{W} & \mathrm{Q} & \mathrm{N} & \mathrm{P} & \mathrm{V} & \mathrm{A} & \mathrm{W} & \mathrm{Q} & \mathrm{N} & \mathrm{P} & \mathrm{V} & \mathrm{I} & 139\end{array}$ CCA GCT AGG CAG ACC CCA CCA GCC TGG CAG AAC CCA GTC GCT TGG CAG AAC CCA GTG ATT 1061

$\begin{array}{lllllllllllllllllllllllll}\text { W } & \mathrm{P} & \mathrm{N} & \mathrm{P} & \mathrm{V} & \mathrm{I} & \mathrm{W} & \mathrm{Q} & \mathrm{N} & \mathrm{P} & \mathrm{V} & \mathrm{I} & \mathrm{W} & \mathrm{P} & \mathrm{N} & \mathrm{P} & \mathrm{I} & \mathrm{V} & \mathrm{W} & \mathrm{P} & 159\end{array}$ TGG CCA AAC CCA GTA ATC TGG CAG AAC CCA GTG ATC TGG CCA AAC CCC ATT GTC TGG CCC 1121 $\begin{array}{lllllllllllllllllllllll}\text { G } & P & \text { V } & \text { V } & \text { W } & \text { P } & \text { N } & \text { P } & \text { L } & \text { A } & \text { W } & \text { Q } & \text { N } & \text { P } & \text { P } & \text { G } & \text { W } & \text { Q } & \text { T } & \text { P } & 179\end{array}$ GGC CCT GTT GTC TGG CCG AAT CCA CTG GCC TGG CAG AAT CCA CCT GGA TGG CAG ACT CCA 1181

$\begin{array}{lllllllllllllllllllllll}P & G & W & Q & P & P & G & G & W & Q & G & P & P & D & W & \mathcal{Q} & G & P & P & D & 199\end{array}$ CCT GGA TGG CAG ACC CCA CCG GGC TGG CAG GGT CCT CCA GAC TGG CAA GGT CCT CCT GAC 1241

$\begin{array}{llllllllllllllllllllllllll}\text { W } & P & \text { L } & \text { P } & \text { P } & \text { D } & \text { W } & \text { P } & \text { L } & \text { P } & \text { P } & \text { D } & \text { W } & \text { P } & \text { L } & \text { P } & \text { T } & \text { D } & \text { W } & \text { P } & 219\end{array}$ TGG CCG CTA CCA CCC GAC TGG CCA CTG CCA CCT GAT TGG CCA CTT CCC ACT GAC TGG CCA 1301

$\begin{array}{llllllllllllllllllllll}I & P & P & D & \text { W } & \text { I } & \text { P } & \text { A } & \text { D } & \text { W } & \text { P } & \text { I } & \text { P } & \text { P } & \text { D } & \text { W } & \text { Q } & \text { N } & \text { I } & R & 239\end{array}$ CTA CCA CCT GAC TGG A

$\begin{array}{lllllllllllllllllllllll}\mathrm{P} & \mathrm{S} & \mathrm{P} & \mathrm{N} & \mathrm{L} & \mathrm{R} & \mathrm{P} & \mathrm{S} & \mathrm{P} & \mathrm{N} & \mathrm{S} & \mathrm{R} & \mathrm{A} & \mathrm{S} & \mathrm{Q} & \mathrm{N} & \mathrm{P} & \mathrm{G} & \mathrm{A} & \mathrm{A} & 259\end{array}$ CCC TCG CCT AAC CTG CGC CCT TCT CCC AAC TCG CGT GCC TCA CAG AAC CCA GGT GCT GCA 1421

$\begin{array}{llllllllllllllllllllllllllllll}Q & \mathrm{P} & \mathrm{R} & \mathrm{D} & \mathrm{V} & \mathrm{A} & \mathrm{L} & \mathrm{L} & \mathrm{Q} & \mathrm{E} & \mathrm{R} & \mathrm{A} & \mathrm{N} & \mathrm{K} & \mathrm{I} & \mathrm{V} & \mathrm{K} & \mathrm{Y} & \mathrm{L} & \mathrm{M} & 279\end{array}$ CAG CCC CGA GAT GTG GCC CTT CTT CAG GAA AGA GCA AAT AAG TTG GTC AAG TAC TTG ATG 1481 F2

$\begin{array}{llllllllllllllllllllll}\mathrm{L} & \mathrm{K} & \mathrm{D} & \mathrm{Y} & \mathrm{T} & \mathrm{K} & \mathrm{V} & \mathrm{P} & \mathrm{I} & \mathrm{K} & \mathrm{R} & \mathrm{S} & \mathrm{E} & \mathrm{M} & \mathrm{L} & \mathrm{R} & \mathrm{D} & \mathrm{I} & \mathrm{I} & \mathrm{R} & 299\end{array}$ CTT AAG GAC TAC ACA AAG GTG CCC ATC AAG CGC TCA GAA ATG CTG AGA GAT ATC ATC CGT 1541

$\begin{array}{lllllllllllllllllllllllllllll}\mathrm{E} & \mathrm{Y} & \mathrm{T} & \mathrm{D} & \mathrm{V} & \mathrm{Y} & \mathrm{P} & \mathrm{E} & \mathrm{I} & \mathrm{I} & \mathrm{E} & \mathrm{R} & \mathrm{A} & \mathrm{C} & \mathrm{F} & \mathrm{V} & \mathrm{L} & \mathrm{E} & \mathrm{K} & \mathrm{K} & 319\end{array}$ GAA TAC ACT GAT GTT TAT CCA GAA ATC ATT GAA CGT GCA TGC TTT GTC CTA GAG AAG AAA 1601

FIG. 1. Translation of the portion of the complementary strand of the THC 179960, which encodes MAGED1. Boldface amino acids, portion of the MAGED1 that is repetitive; boldface underlined amino aicds, portion with high degree of homology to mouse ESTs (see Fig. 2); boldface nucleotides, sequences corresponding to either the primers or their complementary sequences (see, Materials and Methods); dashed arrows underlining the primers indicate primers' orientation; T, in the THC179960 there is W, i.e., A/T. The construct pMAGED1 was generated by cloning the F1/R1 amplified portion of the THC 179960 into the vector pCR2.1. 


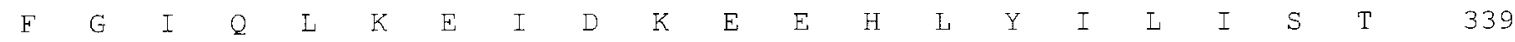
TTT GGG ATT CAA CTG AAA GAA ATT GAC AAA GAA GAA CAC CTG TAT ATT CTC ATC AGT ACC 1661

$\begin{array}{llllllllllllllllllllllllllll}\mathrm{P} & \mathrm{E} & \mathrm{S} & \mathrm{L} & \mathrm{A} & \mathrm{G} & \mathrm{I} & \mathrm{L} & \mathrm{G} & \mathrm{T} & \mathrm{T} & \mathrm{K} & \mathrm{D} & \mathrm{T} & \mathrm{P} & \mathrm{K} & \mathrm{L} & \mathrm{G} & \mathrm{I} & \mathrm{L} & 359\end{array}$ CCC GAG TCC CTG GCT GGC ATA CTG GGA ACG ACC AAA GAC ACA CCC AAG CTC GGT CTC CTC 1721

$\begin{array}{lllllllllllllllllllllllll}\mathrm{L} & \mathrm{V} & \mathrm{I} & \mathrm{L} & \mathrm{G} & \mathrm{V} & \mathrm{I} & \mathrm{F} & \mathrm{M} & \mathrm{N} & \mathrm{G} & \mathrm{N} & \mathrm{R} & \mathrm{A} & \mathrm{S} & \mathrm{E} & \mathrm{A} & \mathrm{V} & \mathrm{L} & \mathrm{W} & 379\end{array}$ TTG GTG ATT CTG GGT GTC ATC TTC ATG AAT GGC AAC CGT GCC AgT GAg GCT GTC CTC IGG 1781

$\begin{array}{llllllllllllllllllllllllllll}\text { E } & \text { A } & \text { L } & \text { R } & \text { K } & \text { M } & \text { G } & \text { L } & \text { R } & \text { P } & \text { G } & \text { V } & \text { R } & \text { H } & \text { P } & \text { I } & \text { L } & G & \text { D } & \text { L } & 399\end{array}$ GAG GCA CTA CGC AAG ATG GGA CTG CGT CCT GGG GTG AGA CAT CCC CTC CTT GGA GAT CTA 1841

$\begin{array}{lllllllllllllllllllllllll}K & \mathrm{~L} & \mathrm{~L} & \mathrm{~L} & \mathrm{~T} & \mathrm{Y} & \mathrm{E} & \mathrm{F} & \mathrm{V} & \mathrm{K} & \mathrm{Q} & \mathrm{K} & \mathrm{Y} & \mathrm{L} & \mathrm{D} & \mathrm{Y} & \mathrm{R} & \mathrm{R} & \mathrm{V} & \mathrm{P} & 419\end{array}$ AGG AAA CTT CTC ACC TAT GAG TTT GTA AAG CAG AAA TAC CTG GAC TAC AGA CGA GTG CCC 1901

$\begin{array}{lllllllllllllllllllllllllllllll}\mathrm{N} & \mathrm{S} & \mathrm{N} & \mathrm{P} & \mathrm{P} & \mathrm{E} & \mathrm{Y} & \mathrm{E} & \mathrm{F} & \mathrm{L} & \mathrm{W} & \mathrm{G} & \mathrm{L} & \mathrm{R} & \mathrm{S} & \mathrm{Y} & \mathrm{H} & \mathrm{E} & \mathrm{T} & \mathrm{S} & 439\end{array}$ AAC AGC AAC CCC CCG GAG TAT GAG TTC CTC TGG GGC CTC CGT TCC TAC CAT GAG ACT AGC 1961

$\begin{array}{llllllllllllllllllllllllllll}K & M & K & V & I & R & F & I & A & E & V & Q & K & R & D & P & R & D & W & T & 459\end{array}$ AAG ATG AAA GTG CTG AGA TTC ATT GCA GAG GTT CAG AAA AGA GAC CCT CGT GAC TGG ACT 2021 R3

$\begin{array}{llllllllllllllllllllllllll}\mathrm{A} & Q & \mathrm{~F} & \mathrm{M} & \mathrm{E} & \mathrm{A} & \mathrm{A} & \mathrm{D} & \mathrm{E} & \mathrm{A} & \mathrm{L} & \mathrm{L} & \mathrm{D} & \mathrm{A} & \mathrm{L} & \mathrm{D} & \mathrm{A} & \mathrm{A} & \mathrm{A} & \mathrm{E} & 479\end{array}$ GCA CAG TTC ATG GAG GCT GCA GAT GAG GCC TTG GAT GCT CTG GAT GCT GCT GCA GCT GAG 2081 $\begin{array}{lllllllllllllllllllllllllllll}\text { A } & E & A & R & A & E & A & R & T & R & M & G & I & G & D & E & A & V & S & G & 499\end{array}$ GCC GAA GCC CGG GCT GAA GCA AGA ACC CGC ATG GGA ATT GGA GAT GAG GCT GTG TCT GGG 2141

$\begin{array}{lllllllllllllllllllllll}\mathrm{P} & \mathrm{W} & \mathrm{W} & \mathrm{D} & \mathrm{D} & \mathrm{I} & \mathrm{E} & \mathrm{E} & \mathrm{E} & \mathrm{L} & \mathrm{L} & \mathrm{T} & \mathrm{W} & \mathrm{D} & \mathrm{E} & \mathrm{E} & \mathrm{G} & \mathrm{D} & \mathrm{F} & 519\end{array}$ CCC TGG AGC TGG GAT GAC ATT GAG TTT GAG CTG CTG ACC TGG GAT GAG GAA GGA GAT TTT 2201

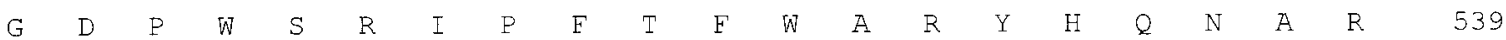
GGA GAT CCC TGG TCC AGA ATT CCA TTT ACC TTC TGG GCC AGA TAC CAC CAG AAT GCC CGC 2261

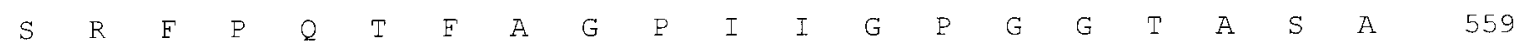
TCC AGA TTC CCT CAG ACC TTT GCC GGT CCC ATt ATt GGT CCT GGT GGT ACA GCC AGT GCC 2321 $\begin{array}{llllllllllllllll}N & F & A & A & N & F & G & A & I & G & F & F & W & V & E\end{array}$ AAC TTC GCT GCC AAC TTT GGT GCC ATT GGT TTC TTC TGG GTT GAG TGAGATGTTGGATATTGCTA 2386 $R 1$

TCAATCGCAGTAGTCTITCCCCTGTGTGAGCTGAAGCCTCAGATTCCTTCTAAACACAGCTATCTAGAGAGCCACATCCT 2466 RHF GTTGACTGAAAGTGGCATGAAGATAAATT TATT TGCTGTTCCTTGTCTACTGCTTTTTTTCCCCTTGTGTGCTGTCAAGT 2546 RHR

\section{FIG. 1-Continued}

(which is the complement of C:CAT at position 19591962 in THC179960) (Fig. 1).

\section{Expression of MAGED1}

RT-PCR using total RNA from BMSC from three $M M$ patients as well as three healthy donors showed that MAGED1 was expressed in all six samples (Fig. 3A). No amplification was obtained with primers F1 and R1 off the human genomic DNA. This, in fact, proves that primers $\mathrm{F} 1$ and $\mathrm{R} 1$ recognize different ex- ons of the MAGED1 gene. Since RDA is designed to clone out qualitative differences between two different cell types (tissues) (Hubank and Schatz, 1994), we conclude that identification of MAGED1 in the context of RDA was fortuitous. Thus, MAGED1 does not represent a gene that is a true differentially expressed gene in BMSC of MM patients compared to healthy donors. Expression of MAGED1 in the normal BMSC, and also the fact that some of the ESTs assembled into TCH179960 were obtained from the libraries made 
A

consensus

human MAGE-D1

human MAGE-like

human MAGE-B3

mouse SMAGE-1
XXXXKXjaXnjkMLX XaXnrermXdPEIcp njXXXbEXXFGcrLK paDXrrrXYcLcjrX KDYTKVPIKRSEMLR DIIREYTDVYPEIIE RACFVLEKKFGIQLK EIDKEEHLYILISTP 340 KDQTKIPIKRSDMLK DIIKEYTDVYPEIIE RAGYSLEKVFGIQLK EIDKNDHLYILLSTL 352 MYKMKKPIMKADMLK IVQKSHKNCFPEILK KASFNMEVVFGVDLK KVDSTKDSYVLVSKM 184 KFKMKEAVTRSEMLA VVNKKYKEQFPEILR RTSARLELVFGLELK EIDPSTHSYLLVGKL 225

\section{consensus}

human MAGE-D1

human MAGE-like

human MAGE-B3

mouse SMAGE-1
XgjXXGXcjrXXXXP nXGLLbXcLjaIFMr GNXjiEXXcWoXLrX cXcXXGXrHXcfGkX E-SLAGILGTTKDTP KLGLLLVILGVIFMN GNRASEAVLWEALRK MGLRPGVRHPLLGDI 399 EPTDAGILGTTKDSP KLGLLMVLLSIIFMN GNRSSEAVIWEVLRK LGLRPGIHHSLFGDV 412 DLPNNGTVTRGRGFP KTGLLLNLLGVIFMK GNCATEEKIWEFLNK MRIYDGKKHEIFGEP 244 GLSTEGSLSSNWGLP RTGLLMSVLGVIFMK GNRATEQEVWQFLHG VGVYAGKKHLIFGEP 285

\section{consensus}

human MAGE-D1

human MAGE-1ike

human MAGE-B3

mouse SMAGE-1
ppfcgXkfVnXrYLk YXpVPXS1PjrYEFf WGXRjeXETiKMKVL pfXXpVrXrXPrXdX RKLLTYEFVKQKYLD YRRVPNSNPPEYEFL WGLRSYHETSKMKVL RFIAEVQKRDPRDWT 459 KKLITDEFVKQKYLD YARVPNSNPPEYEFF WGLRSYYETSKMKVL KFACKVQKKDPKEWA 472 RKLITQDLVKLKYLE YRQVPNSNPARYEFL WGPRAHAETSKMKVL EFWAKVNKTVPSAFQ 304 EEFI-RDVVRENYLE YRQVPGSDPPSYEFL WGPRAHAETTKMKVL EVLAKVNGTVPSAFP 344

\section{consensus}

human MAGE-D1

human MAGE-like

human MAGE-B3

mouse SMAGE-1
XXdXXAXrXgggggr AXXXXXXXXrhXhXX gjnggggghXXXXjj AQEMEAADE---ALD ALDAAAAEAEARAEA RTRMGI--GDEAVSG 499 AQYREAMEA---DLK AAAEAAAEAKARAEI RARMGIGLGSENAAG 514 EWYEEALRDEEERVQ AAAMLNDGSSAMGRK CSK-----AKASSSS 344 NLYQLALRD-----Q AGGVPRRRVQGKGVH -SK-----APSQKSS 378

\section{B}

human MAGE-D1 consensus

mouse AA543728
QTPLA WQNPSG WONQTA RQTPPA- RQSPPA RQTPPA WQNPVA QTPLA WQNPSG WQNQTA RQTPPA- RQSPPA RQTP-A WQNPVA QTPLA WQNPSG WQNQTA RQTPPAA RQSPPA RQTPSA WQNPVA human MAGE-D1 consensus mouse AA543728
WONPVI WPNPVI WQNPVI WPNPIV WPGPVV WPNP WQNPVI WPNPVI WQNPVI WPNPIV WPGP+V WPNP WQNPVI WPNPVI WQNPVI WPNPIV WPGPIV WPNP

FIG. 2. (A) The alignment of the C-terminal portion of the MAGED1 (amino acids 281-499, based on the translation of THC179960/ MAGED1) with the other members of the human and mouse MAGE family. Uppercase boldface type, identical amino acids; lowercase bol dface type, conserved substitutions; $X$, nonconserved amino acid; $g$, gap in the consensus sequence. (B) Alignment of the repetitive portion of the MAGED1 with the translation of the mouse EST AA543728. TBASTN search at dot.imgen.bcm.tmc.edu:9331 was carried out to identify homologies at the protein level.

from normal adult tissues, prompted us to examine the expression of MAGED1 in a more detailed fashion among a variety of other tissue sources. PCR amplification on the CDNAs from different normal adult tissues revealed that MAGED1 was expressed in a variety of normal tissues other than normal BMSC. Specifically, a band of the expected size, i.e., $\sim 1.7 \mathrm{~kb}$, amplified off the heat-inactivated samples of cDNA libraries of normal adult liver, heart, skeletal muscle, brain, pancreas, lung, kidney, and placenta (Fig. 3B). Furthermore, Northern analysis of MAGED1 expression using the probes $F 1 R 2$ and $F 2 R 3$, recognizing the $5^{\prime}$ and $3^{\prime}$ ends of the MAGED1 mRNA, respectively, confirmed our belief that MAGEDI represents a member of the MAGE gene family with a distinctly different expression pattern than that of known members of this gene family. Namely, the expression level of the MAGED1 mRNA in normal adult pancreas, adrenal medulla, thyroid gland, adrenal cortex, heart, brain, and placenta is quantitatively comparable to that in testis and fetal liver (Fig. 4). In addition to our experimental data, the ESTs mapping to TCH179960 indicate that MAGED1 is also expressed in a variety of tumors and fetal tissues (Table 1 ). Thus, we conclude that MAGED1 is a gene expressed in a broad range of normal tissues throughout development and in different types of tumors. The size of the transcript that we identified with the MAGED1 probe was $\sim 2.6 \mathrm{~kb}$, indicating that THC179960 represents the full-length (or nearly fulllength) cDNA of MAGED1. In addition to the 574amino-acid protein coding region, it also contains 5' untranslated (644 bp) and 3' untranslated (238 bp) regions (data not shown).

\section{Chromosomal Location of MAGE-D1}

Chromosome mapping with Stanford Genome Center G3 RH panels revealed that the MAGED1 gene resides on Xp11.23. Using primers RHF and RHR, 


\section{TABLE 1}

The List of Tissues, ${ }^{a}$ Other Than Those in Figs. 3 and 4, That Express the MAGED1

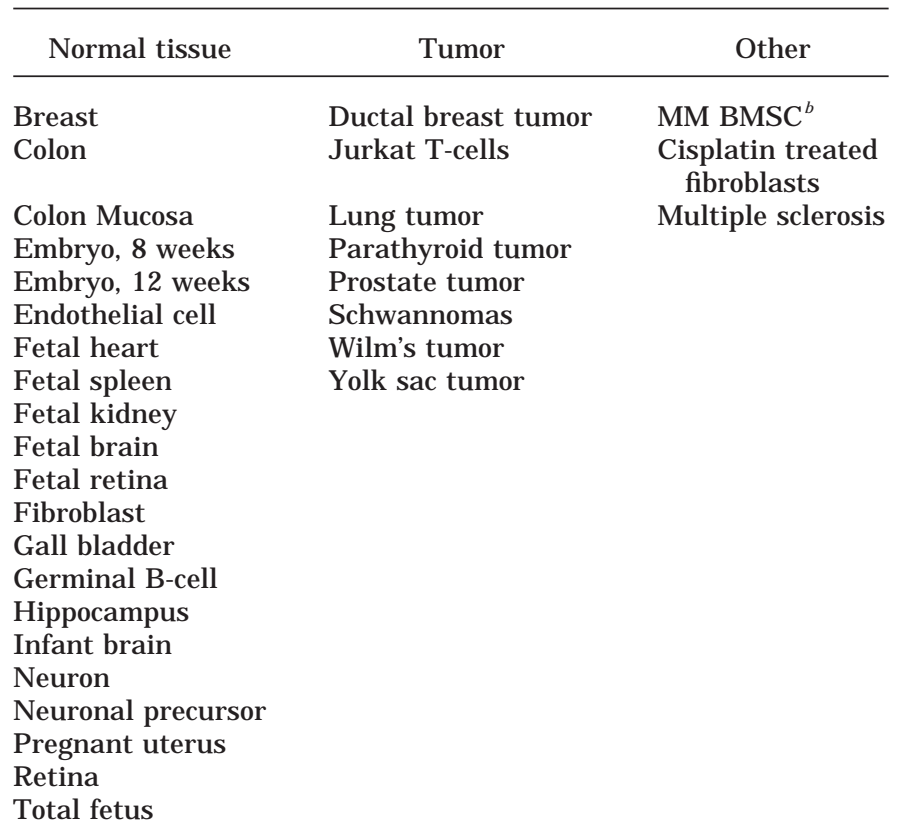

a Data from the TIGR Human Gene Index (HGI) THC Report THC179960, except for MM BMSC.

${ }^{\mathrm{b}} \mathrm{MM}$ BMSC are not considered malignant cells.

MAGED1 was linked to marker AFM119xd6 (DXS1039) with a lod score of 8.5 at a distance of 13 cR (390 kb) with the G3 panel from the Stanford Genome Center. This marker is mapped to band Xp11.23. Although the X chromosome is the typical location for the genes of the MAGE family (De Plaen \& al., 1994), the band p11.23 has not been previously reported to contain a MAGE gene.

\section{DISCUSSION}

Contrary to the previous studies, suggesting that the expression of various MAGEs in normal adult tissues is restricted to testis only [with the exception of MAGE-3 and MAGE-4, which are also expressed in placenta (De Plaen et al., 1994)], our data provide evidence that the member of the MAGE family that we have identified, i.e., MAGED1, is expressed fairly ubiquitously. Like the other MAGEs, MAGED1 is expressed in variety of fetal tissues and tumors (Table 1). At this point, we do not know whether or not MAGED1 can act as a tumor antigen.

The structure of the MAGED1 protein is reminiscent of that of another member of the MAGE family, MAGE C1. Similarly to MAGE-C1 protein, MAGEDI contains a repetitive region in its unique, $\mathrm{N}$-terminal portion and shares homology with the other members of the MAGE gene family in its C-terminal half. Although the MAGED1 hexameric repeats are structurally unre lated to the three different types of imperfect repeats present in the MAGE-C1 protein, they share analogy with the MAGE-C1 repeats in that the repeats of either protein are of low complexity. Numerically, $42 \%$ of the repetitive region of MAGED1, that is, 68 of 161 amino acids in the repetitive region of MAGED1, is made of proline, serine, and glutamine (Fig. 1). Likewise, 53\% of the repetitive portion of the MAGE-Cl is contributed by the same amino acids (Lucas \& al., 1998). As shown in Fig. 2B, the repetitive portion of MAGED1 seems to have been conserved in mammals. We hypothesize that the mouse EST aligned with the human MAGED1 repetitive portion represents the mouse orthologue of human MAGED1. A homology search with the human MAGED1 repetitive portion did not reveal any other potential orthologues of MAGED1. Nevertheless, considering the evolutionary distance of human and mouse, and the high degree of homology between human and mouse sequences (Fig. 2B), one may assume the existence of MAGED1 orthologues in other mammals as well. As for the function of the repetitive portion of MAGED1, and the MAGE family proteins in general, it is unknown. For the time being, however, one may say that not all MAGE family genes are of tumor/embryo/adult testis-specific expression. Based on this study and our unpublished data, we postulate that there is a group of MAGE family genes that is expressed in a wide variety of normal adult tissues.

Recent studies have al ready broadened the knowledge about the expression of the MAGE and PAGE/GAGE family proteins. As shown by McCurdy et al. (1998) MAGE Xp-2 may be expressed in a case of systemic lupus erythematosus. PAGE-1, a GAGE-like gene belonging to another, structurally unrelated family of tumor/embryo/ adult testis-restricted genes, is expressed in normal prostate, testis, uterus, fallopian tube, and placenta, leading the authors to suggest that PAGE-1 might be involved in sex determination (Brinkmann \& al., 1998). Also, RAGE-1, a member of yet another tumor antigen family, structurally unrelated to either the MAGE or the GAGE families, has been found to be expressed in normal adult retina (Gaugler et al., 1996). Thus, further studies are necessary to gain more insight into the physiology of the MAGE gene family.

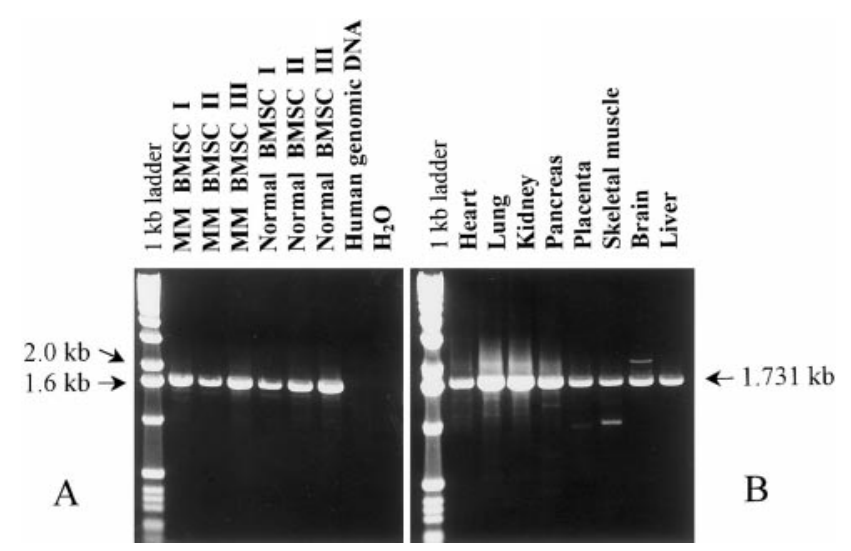

FIG. 3. (A) RT-PCR on total RNA from BMSC from MM patients and normal healthy donors. (B) PCR on heat-inactivated CDNA Iibrary aliquots. 


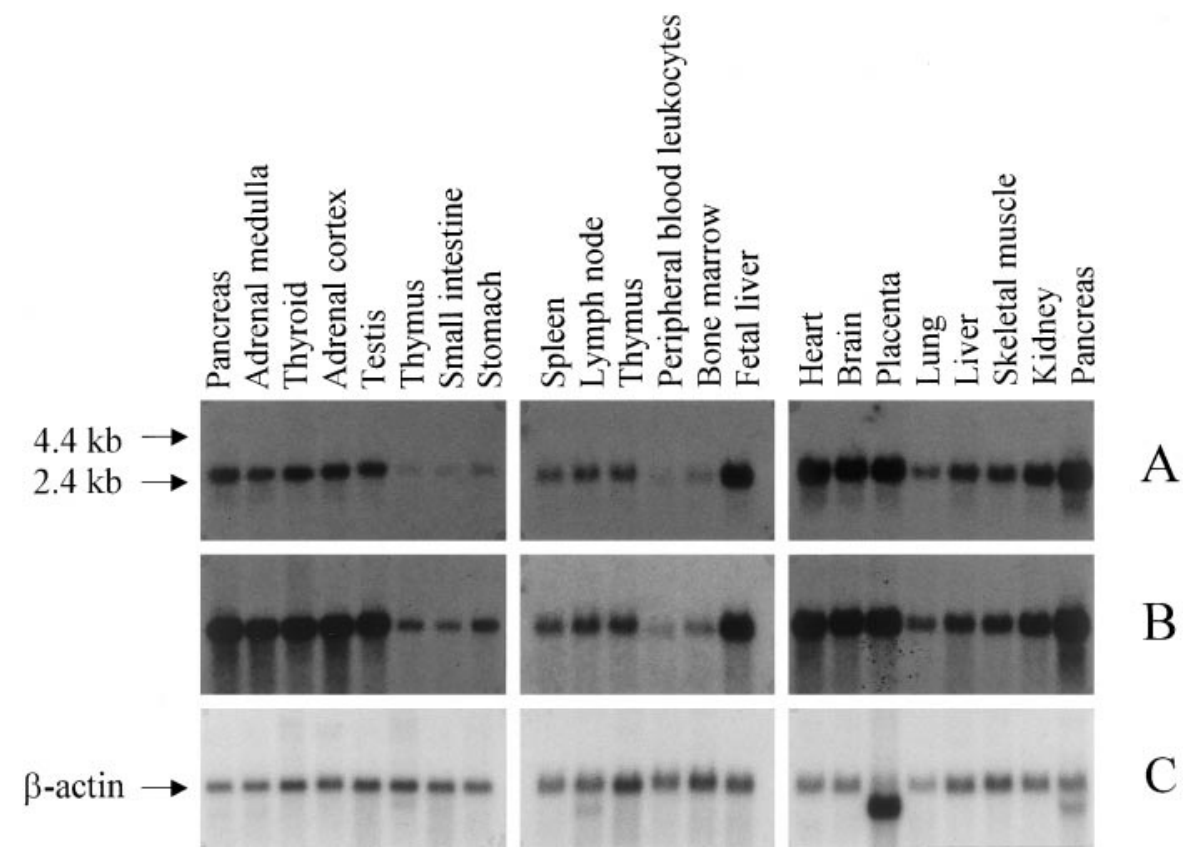

FIG. 4. (A) The MTBs were hybridized with the $\mathrm{F} 1 / \mathrm{R} 2$ probe and washed five times in $2 \times \mathrm{SSC} / 1 \% \mathrm{SDS}$ at $65^{\circ} \mathrm{C}(20 \mathrm{~min})$, followed by two 20 washes in $0.1 \times \mathrm{SSC} / 0.5 \%$ SDS at $60^{\circ} \mathrm{C}$. The blots were exposed to Kodak BioMax MS film using Kodak BioMax intensifying screens at $-80^{\circ} \mathrm{C}$ for $10 \mathrm{~h}$. (B) The same MTBs hybridized with the F $2 / \mathrm{R} 3$ probe and washed five times in $2 \times \mathrm{SSC} / 1 \% \mathrm{SDS}$ at $65^{\circ} \mathrm{C}$ ( 20 min), followed by two $20-\mathrm{min}$ washes in $0.1 \times \mathrm{SSC} / 0.5 \% \mathrm{SDS}$ at $65^{\circ} \mathrm{C}$. The blots were exposed to $\mathrm{Kodak} \mathrm{BioMax} \mathrm{MS}$ film at $-80^{\circ} \mathrm{C}$ for $10-20 \mathrm{~h}$. (C) The same MTBs hybridized with the $\beta$-actin probe and washed five times in $2 \times \mathrm{SSC} / 1 \% \mathrm{SDS}$ at $65^{\circ} \mathrm{C}$ ( 20 min), followed by three $20-\mathrm{min}$ washes in in $0.1 \times \mathrm{SSC} / 0.5 \% \mathrm{SDS}$ at $65^{\circ} \mathrm{C}$. The blots were exposed to Kodak BioMax MS film at room temperature for 30 min.

\section{REFERENCES}

Adams, M. D., Kerlavage, A. R., Fields, L., and Venter, J . C. (1993). 3400 new expressed sequence tags identify diversity of transcripts in human brain. Nat. Genet. 4: 256-267.

Boël, P., Wildmann, C., Sensi, M. L., Brasseur, R., Renauld, J . C., Coulie, P., Boon, R., and van der Bruggen, P. (1995). BAGE: A new gene encoding an antigen recognized on human melanomas by cytolytic T Iymphocytes. Cell 2: 167-175.

Brinkmann, U., Vasmatzis, G., Byungkook, L., Yerushalmi, N., Essand, M., and Pastan, I. (1998). PAGE-1, an X chromosome-linked GAGEline gene that is expressed in normal and neoplastic prostate, testis, and uterus. Proc. Natl. Acad. Sci. USA 95: 10757-10762.

De Plaen, E., Arden, K., Traversari, C., Gaforio, J . J ., Szikora, J -P., De Smet, C., Brasseur, F., van der Bruggen, P., Lethe, B., Lurquin, C., Brasseur, R., Chomez, P., De Baker, O., Canence, W., and Boon, T. (1994). Structure, chromosomal location, and expression of 12 genes of the MAGE family. I mmunogenetics 40: 360-369.

Gartner, S. M., and Kaplan, H. S. (1980). Long-term culture of human bone marrow cells. Proc. Natl. Acad. Sci. USA 77: 475647569.

Gaugler, B., Brouwenstijn, N., Vantomme, V., Szikora, J -P., Van der Spek, C. W., Patard, J -J ., Boon, T., Schrier, P., and Van den Eynde, B. J. (1996). A new gene coding for an antigen recognized by autologous cytolytic T Iymphocytes on a human renal carcinoma. I mmunogenetics 44: 323-330.

Hu, X., Chakraborty, N. G., Sporn, Kurzman, S. K., Ergin, M. T., J . R., and Mukherji, B. (1996). Enhancement of cytolytic T Iymphocyte precursor frequency in melanoma patients following immunization with the MAGE-1 peptide loaded antigen presenting cell-based vaccine. Cancer Res. 56: 2479-2483.

Hubank, M., and Schatz, D. G. (1994). Identifying differences in mRNA expression by representational difference analysis of cDNA. Nucleic Acids Res. 22: 5640-5648.

Kocher, D., Schultz-Tater, E., Gudat, F., Schaefer, C., Casorati, C., J uretic, A., Williman, T., Harder, F., Heberer, M., and Spagnoli,
G. C. (1995). Identification and intracellular location of MAGE-3 gene product. Cancer Res. 55: 2236-2239.

Kozak, M. (1987). At least six nucleotides preceding the AUG initiator codon enhance translation in mammalian cells. J. Mol. Biol. 196: 947-950.

Lethe, B., Lucas, S., Michaux, L., Godelaine, D., Serrano, A., De Plaen, E., and Boon, T. (1998). LAGE-1, a new gene with tumor specificity. Int. J . Cancer 76: 903-908.

Lucas, S., De Smet, C., Arden, K. C., Viars, C. S., Lethe, B., Lurquin, C., and Boon, T. (1998). Identification of a new MAGE gene with tumor specific expression by representational difference analysis. Cancer Res. 58: 743-752.

Marchand, M., Weynants, P., Rankin, E., Arienti, F., Belli, F., Rarmiani, G., Cascinelli, N., Bourlond, A., Vanwijck. R., and Humblet, Y. (1995). Tumor regression responses in melanoma patients treated with a peptide encoded by gene MAGE-3. Int. J . Cancer 63: 883- 885.

McCurdy, D. K., Tai, L-Q., Nguyen, J ., Wang, Z., Yang, H-M., Udar, N., Naiem, F., Concannon, P., and Gatti, R. A. (1998). MAGE Xp-2: A member of the MAGE gene family isolated from an expression library using systemic lupus erythematosus sera. Mol. Genet. Metabol. 63: 3-13.

Mukherji, B., Chakraborty, N. G., Yamasaky, S., Okino, T., Yamase, H., Sporn, J . R., Kurzman, S. K., Ergin, M. T., Ozols, J ., Meehan, J ., and Mauri, F. (1995). Induction of antigen-specific cytolytic T cells in situ in human melanoma by immunization with synthetic peptide-pulsed autologous antigen presenting cells. Proc. Natl. Acad. Sci. USA 92: 8078-8082.

Rettig, M. B., Ma, H. J ., Vescio, R. A., Põld, M., Schiller, G., Belson, D., Savage, A., Nishikubo, C., Wu, C., Fraser, J ., Said, J. W., and Berenson, J . R. (1997). Kaposi's sarcoma-associated herpesvirus infection of bone marrow dendritic cells from multiple myeloma patients. Science 276: 1851-1854.

Van den Eynde, B. J ., and van der Bruggen, P. (1997). T cell tumor antigens. Curr. Opin. Immunol. 9: 684-693. 